\title{
Notes on the vocalizations of Large Wood-shrike (Tephrodornis virgatus)
}

Peter Boesman

In the following we briefly analyze and compare voice of the different races of Large Woodshrike (Tephrodornis virgatus). We also try to quantify the extent of any vocal differences using the criteria proposed by Tobias et al. (2010), as a support for taxonomic review. We have made use of sound recordings available on-line from Xeno Canto (XC).

Song of all races (for which recordings are available) is a phrase, consisting of a repeated single note (with the exception of race sy/vicola). This series at first increases in pitch and amplitude, then remains stable with notes nearly identical. Some random examples:

\section{Borneo}

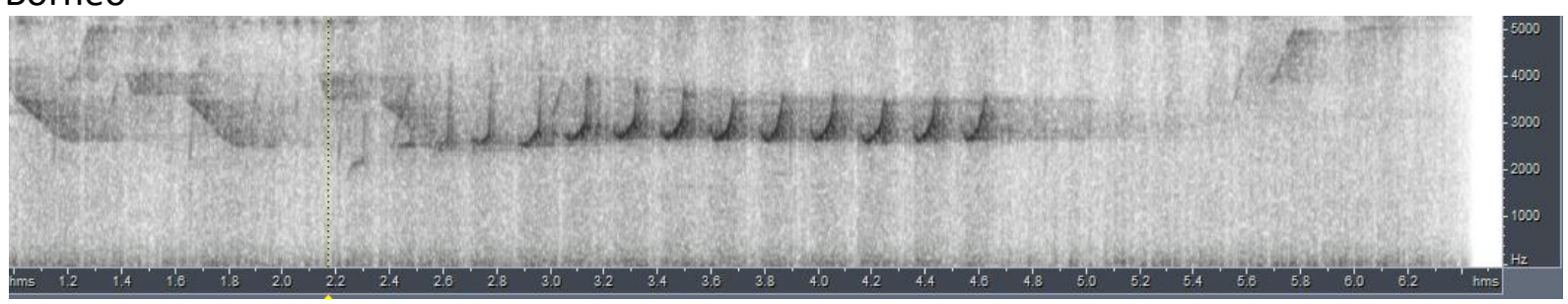

Peninsular Malaysia

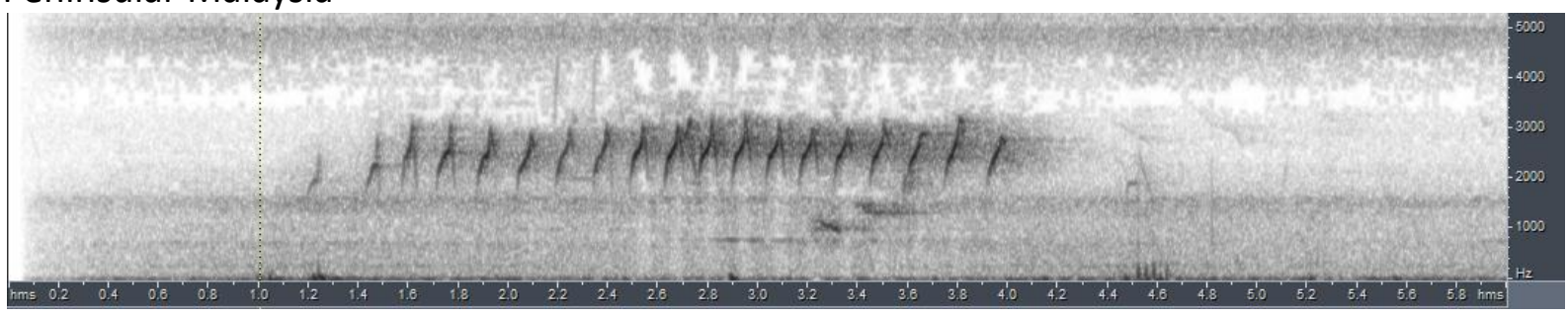

Cambodia

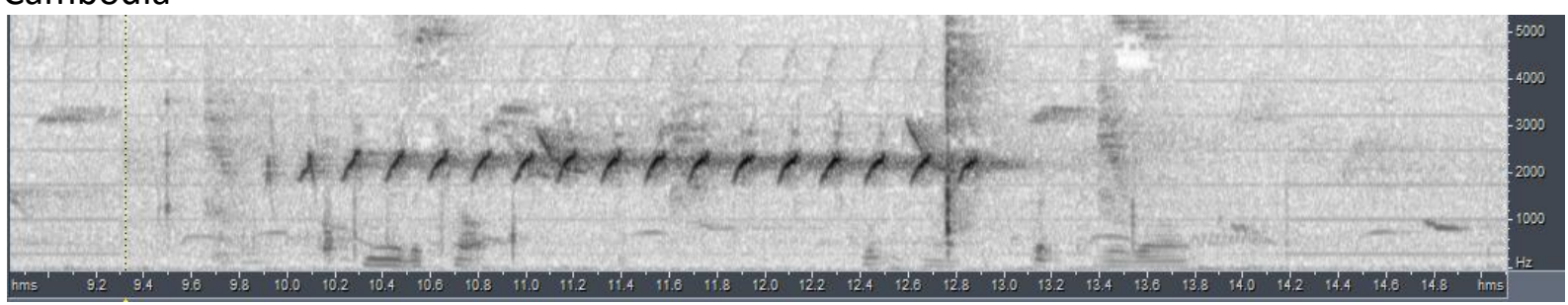

Assam, India

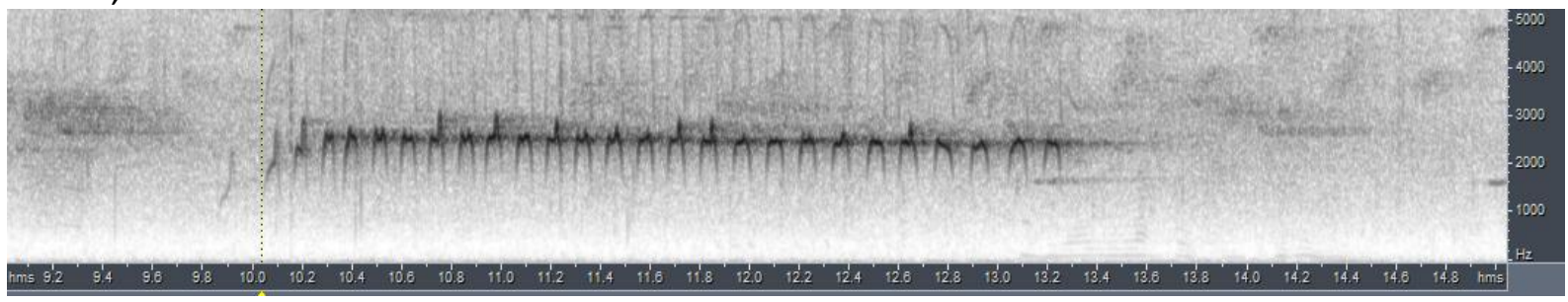



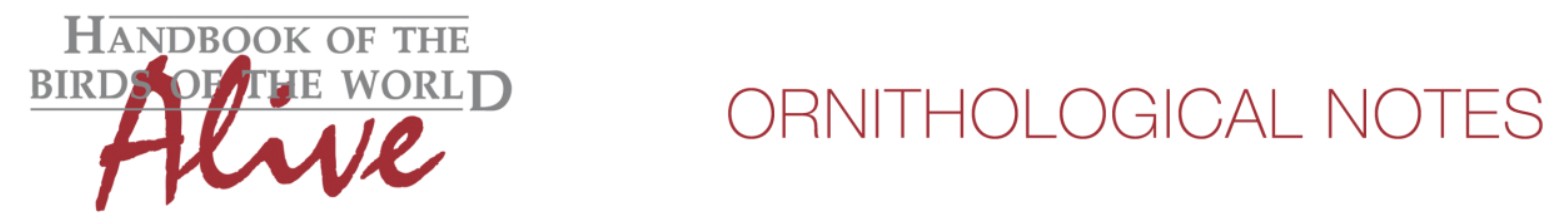

Song of race sy/vicola is quite different: the song phrase consists of two alternating notes (valid over its entire range). Some examples:

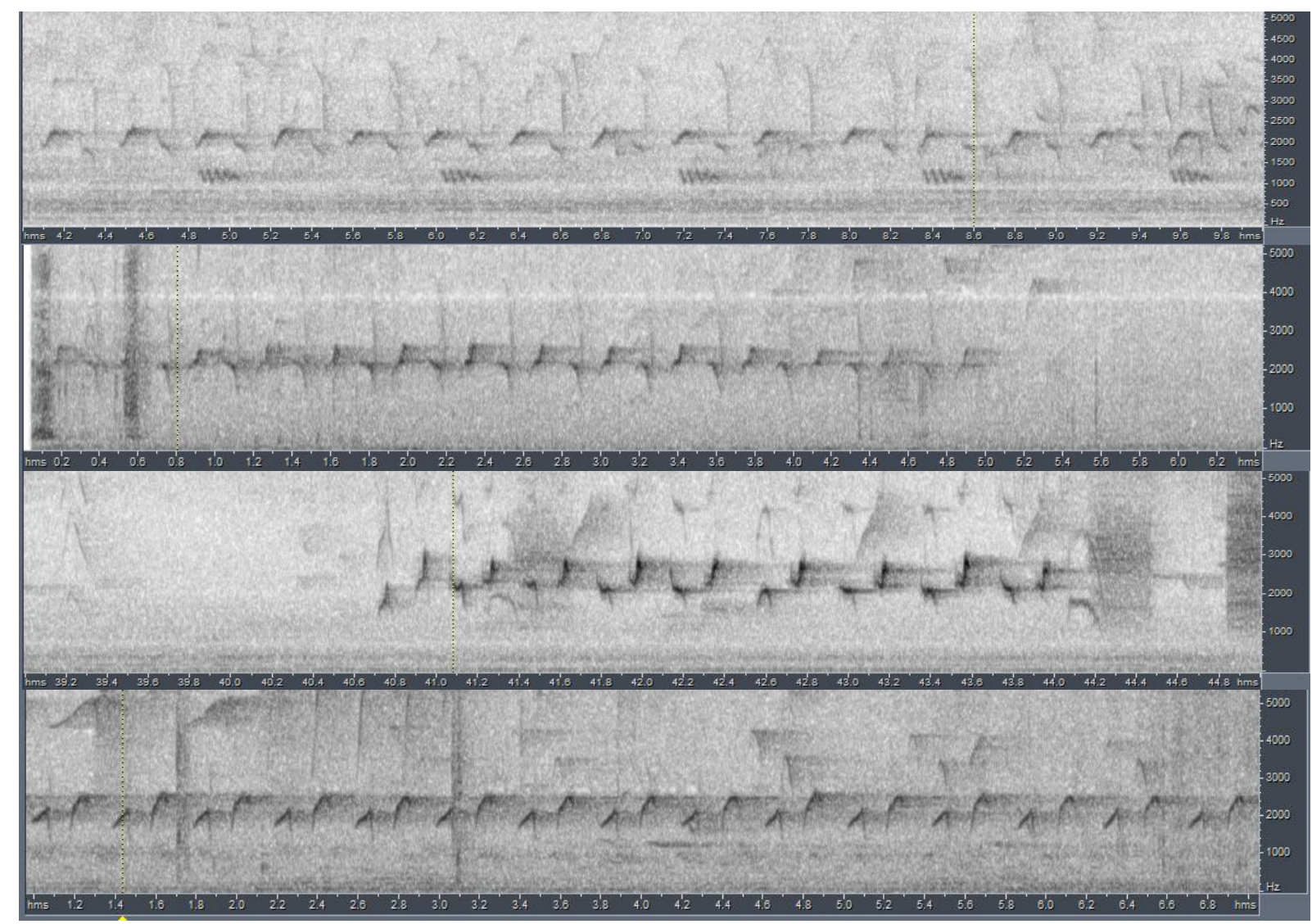

From the above examples, it is clear that the main difference is the single repeated note vs. two different alternating notes (which can be quantified as 1 vs 2, score 4). Other differences are smaller and with considerable overlap, e.g. total length of song in sy/vicola on average is longer (score 1), sylvicola on average doesn't reach that high frequencies (score 1) etc. More recordings (especially of sy/vicola) would be needed to determine with greater accuracy the difference in all basic sound parameters. With present data, when applying Tobias criteria, we obtain a total vocal score of 4-5.

This note was finalized on 16th November 2015, using sound recordings available on-line at that moment. We would like to thank in particular the sound recordists who placed their recordings for this species on XC and ML: Peter Boesman, Eric Cannizzaro, Niels Poul Dreyer, David Edwards, David Farrow, Richard Hoyer, Vir Joshi, Frank Lambert, Albert Lastukhin, Linda Macaulay, Mike Nelson, Vivek Puliyeri, Mark Robbins, Sudipto Roy, Ramit Singal, Klemens Steiof, Arnoud Van den berg, lain Woxvold and Ding Li Yong. 


\section{References}

Tobias, J.A., Seddon, N., Spottiswoode, C.N., Pilgrim, J.D., Fishpool, L.D.C. \& Collar, N.J. (2010). Quantitative criteria for species delimitation. Ibis 152(4): 724-746.

\section{Recommended citation}

Boesman, P. (2016). Notes on the vocalizations of Large Wood-shrike (Tephrodornis virgatus). HBW Alive Ornithological Note 183. In: Handbook of the Birds of the World Alive. Lynx Edicions, Barcelona. (retrieved from http://www.hbw.com/node/932121 on 24 August 2016). 